\title{
Vegetation characteristics influencing site selec- tion by male white-tailed deer in Texas
}

\author{
MATTHEW T. POLLOCK, DONALD G. WHITTAKER, STEPHEN DEMARAIS, AND \\ ROBERT E. ZAIGLIN
}

\begin{abstract}
Authors are wildlife biologist, Florida Game and Fresh Water Fish Commission, Dade City 33525; graduate research assistant, Cooperative Fish and Wildlife Research Unit, University of Wyoming, Laramie 82070; associate professor, Department of Range and Wildlife Management, Texas Tech University, Lubbock 79409; and director, Wildlife Division of Harrison Interests, Ltd., 602 Dorothy Jo Circle, Uvalde Tex. 78801. At the time of the research, M.T.P. and D.G.W. were graduate research assistants, Department of Range and Wildlife Management, Texas Tech University, Lubbock 79409.
\end{abstract}

\begin{abstract}
We studied the effects of vegetation characteristics in southern Texas on site selection by mature, male white-tailed deer (Odocoileus virginianus Raf.). Thirteen, radio-collared animals were monitored during winter, spring, summer, and fall of 1986-87 and 1987-88 to determine area-usage patterns within each animal's respective seasonal home range. After each season, structural vegetation attributes were measured with transect-oriented data collection techniques inside the most heavily used and unused areas of each animal's home range. Comparisons were made between these areas to determine whether site selection by deer was in response to differing vegetation characteristics. In general, the most heavily used areas possessed a greater amount of woody canopy cover ( $\geq 85 \%$ ), woody species richness (18-20), and horizontal screening cover than areas with no use. In contrast, herbaceous densities did not differ between the most heavily used and unused areas. Consequently, habitat management manipulations conducted specifically for mature male white-tailed deer in southern Texas, should include provisions for creation or maintenance of sites possessing dense woody canopy cover, a high number of woody species and dense horizontal screening cover.
\end{abstract}

Key Words: habitat attributes, Odocoileus virginianus, site selection

Mechanical treatment of southern Texas rangeland is widely practiced to suppress growth of existing brush species, and consequently, enhance livestock forage availability (Box and Powell 1965). These brush treatments can negatively impact white-tailed deer habitat because of significant cover reduction (Rollins et al. 1988) and long-term changes in species composition of regrowth brush (Fulbright and Beasom 1987). More than 921,000 ha of rangeland were mechanically treated in southern Texas between 1980-85 (Welch 1986), despite the fact that deer are a primary management focus on many ranches because of potential revenues (Ramsey 1965, Pope et al. 1984).

Research was funded by the Noxious Brush and Weed Control Program, Texas Tech University; Harrison Interests, Ltd.; Houston Livestock Show and Rodeo Association; Caesar Kleberg Foundation for Wildlife Conservation; and College of Agricultural Sciences, Texas Tech University. This is Texas Tech University, College of Agricultural Sciences publication T-9-595. We thank K.R. Johnson, D.A. Dean, C.S. Boyd, and F. Tomlinson and numerous volunteer students for assistance with data collection.

Manuscript accepted 11 Dec. 1993.
Previous investigations, developed to elucidate deer-habitat relationships in Texas, have identified important structural (Steuter and Wright 1980, Wiggers and Beasom 1986) and soil-related features (McMahan and Inglis 1974), but resulting conclusions were drawn from samples comprised of both sexes across all agecohorts. However, deer management programs in south Texas often emphasize production and management of mature male deer because of their significant market value (Teer and Forrest 1968). Because sexual segragations occur in use of deer habitat (Beier and McCullough 1990), a need exists to identify those habitat characteristics which are essential, specifically, to the male segment of the population in south Texas. Further, future inclusion of these vegetation attributes into livestock-oriented brush manipulation programs will help managers facilitate cattle operations while maintaining habitat integrity of the marketable south Texas white-tailed deer resource.

Our objective was to compare vegetation characteristics of the most heavily used area and a nearby unused area within seasonal home ranges of mature, male white-tailed deer during winter, spring, summer, and fall of 1986-87 (year 1) and 1987-88 (year 2). These comparisons were used to test the hypothesis that site selection, by mature male white-tailed deer, was independent of vegetation composition and structure.

\section{Study Area}

We conducted our study on the 42,510-ha Piloncillo Ranch located $6.4 \mathrm{~km}$ south of Catarina, Tex. at the junction of Dimmit, Webb, and LaSalle counties. Total annual precipitation and mean daily temperature average $550 \mathrm{~mm}$ and $21.8^{\circ} \mathrm{C}$, respectively (Stevens and Arriaga 1985) for this area of the Rio Grande Plain vegetation zone (Correll and Johnston 1970).

Vegetation was dominated by a woody brush overstory with a variable herbaceous association dependent upon water availability. Associations of cenizo (Leucophyllum frutescens (Berl) I.M. Johnst.), guajillo (Acacia berlandieri Benth.), blackbrush ( $A$. rigidula Benth.), Texas kidneywood (Eysenhardtia texana Scheele), and brasil (Condalia hookeri M.C. Johnst.) occurred on upland, shallow, sandy loam soils. Upland areas with deep soils were characterized by honey mesquite (Prosopis glandulosa Torr.), prickly pear (Opuntia lindheimeri Engelm), hogplum (Colubrina texensis (T.\&G.) Gray), and desert yaupon (Schaefferia cuneifolia 
Gray). Woody species such as honey mesquite, white brush (Lippia ligustrina (Lag.) Britt.), granjeno (Celtis pallida Torr.), Mexican persimmon (Diospyros texana Scheele), and huisache ( $A$. smalli Isely) occurred in the deep loamy bottomland sites.

Topography varied from areas with little relief to rolling sections interspersed with drainages. Fine sandy loam was the dominant soil type. Clay loam occurred sparsely on the study area (Stevens and Arriaga 1985).

\section{Materials and Methods}

Thirteen male white-tailed deer were captured during 1984-87 using a helicopter and either a drive net (Beasom et al. 1980) or a hand-held netgun (Barrett et al. 1982). Their average age during data collection was $6.1 \pm 1.7$ years based on their estimated age (Severinghaus 1949) at the time of capture. Animals were fitted with $500-\mathrm{g}$ radio packages ${ }^{1}$ operating in $150-151 \mathrm{MHz}$ frequencies. Radio tracking was conducted by taking simultaneous azimuths from 1 of 4 permanent null receiving towers and a mobile null tower (Pollock et al. 1990) using 1 of 45 tracking stations. Estimated bearings were obtained by taking the average of 4 consecutive, independent azimuths to reduce the error limit associated with each error arc to the pooled standard deviation (Springer 1979). Deer were monitored for 2 diel cycles per week, yielding 3,907 and 4,596 locations for year 1 and year 2, respectively. Data were grouped into 4 seasons (winter $=1$ December -28 February; spring = 1 March-31 May; summer =1 June-31 August; fall = 1 September-30 November) within each of 2 years (year $1=1$ December 1986-30 November 1987; year $2=1$ December-30 November 1988). Each seasonal data base contained $\geq 89$ location estimates per animal.

At least 2 hours passed between successive location estimates, affording each animal a realistic opportunity to travel across its home range and assuring independence of subsequent telemetry locations (White and Garrott 1990). The standard error of the receiving system (Springer 1979), determined by comparing bearings from the receiving stations to known bearings measured from an aerial photo, was 1.9 degrees. Error polygons associated with location estimates were calculated on a TRS $80^{2}$ portable computer using BASIC code (White and Garrott 1984). Error polygons were considered acceptable if $\leq 2 \mathrm{ha}$. Error polygon size averaged $( \pm S E)$ $0.60 \pm 0.01$ and $0.55 \pm 0.01$ ha for $1986-87$ and $1987-88$, respectively.

A 2.25 -ha (150- by $150-\mathrm{m})$ grid cell system based on Universal Transverse Mercator System coordinates was overlaid on the study area. Location estimates also were recorded in Universal Transverse Mercator System coordinates and assigned to the appropriate 2.25-ha grid cell. Selection of the most heavily used and unused grid cell within each deer's seasonal convex polygon home range was based on the number of location estimates. The most heavily used grid cell was the cell that contained the most locations. Three criteria were used for the selection of each animal's unused grid cell: it had to lie within an animal's seasonal convex polygon home range; it had to possess a surrounding buffer of unused grid cells, and; it could not possess more than 2 location estimates from other radio-collared deer. Grid cells were identified in the field by using a sighting compass and pacing off the required distance from the nearest antenna location. A transmitter was carried into the cell so the cell-center location could be checked

\footnotetext{
'Advanced Telemetry Systems, Inc., Isanti, Minn.
}

2Tandy Inc., Fort Worth, Tex. from $>3$ tracking stations and adjusted, if needed.

Vegetation was sampled within the most-heavily used and respective unused grid cell for each deer at the end of each season. Five, 30.5-m transects were placed randomly within each grid cell (hereafter referred to as area) to assess measurements of vegetation composition and structure. The number of transects chosen for study was determined by developing initial species-area curves (Cain and Castro 1959) for woody species composition data. We used this same concept to assess canopy cover variability over 5 transects, and subsequently, deemed 5 transects to be sufficient for measurement of the remaining vegetation attributes. Observations for each variable within a transect were used to obtain transect means which in turn were used in formulating a grid cell or area mean.

Canopy cover and height of woody species were measured along each transect. Canopy cover was measured using the line-intercept technique (Canfield 1941), while vegetation height was quantified with the aid of $12-\mathrm{ft}$ poles, calibrated in $1-\mathrm{ft}$ intervals. Canopy cover measurements of individual woody species were summed to obtain individual transect means. Transect values were subsequently averaged and converted to percent canopy cover. Horizontal screening cover was estimated with a profile board (Nudds 1977) located $15 \mathrm{~m}$ perpendicular to each transect on both sides of 4 rand omly located intervals. Coded values ranging from 1 to 5 were scored for 6 height increments with lower values representing less screening cover. Average values for each height interval were converted into a percentage which represented the proportion of visual obstruction. Basal cover (percent of ground covered by herbaceous stems) of both forbs and grasses was measured with a modification of the line point method (Heady et al. 1959), which entailed recording observations when herbacous stems were rooted immediately below points along each transect at $0.6-\mathrm{m}$ intervals.

Statistical analysis followed a randomized block analysis of variance with main effects arranged factorially. Individual deer served as blocks to account for variability among deer in their response to treatments. Treatment factors were area (most-heavily used and unused) and season (winter, spring, summer, and fall). The season effect was included only to determine if site selection, based on a specific variable, was consistent across seasons. By itself, the season effect was not addressed because we assumed it was influenced by environmentally-induced changes in plant phenology and growth. A year effect was not tested for because a randomized block analysis with repeated measures would require that the same animals (i.e., blocks) be used during both years: death loss and subsequent replacement with new animals precluded this approach.

We assumed that all areas within the boundary of each animal's home range were equally available to the animal. Our statistical comparisons identified those vegetation characteristics which differed between used and unused areas of the home range. We infer that vegetation characteristics that differed between used and unused areas are at least partially responsible for the animal's selection of the used area. Because deer were the experimental unit and the study was not replicated across other areas of the Rio Grande Plain vegetation type, care must be exercised when extrapolating our conclusions to locations other than the study area.

Data were transformed (Steel and Torrie 1980) when the Shapiro-Wilk test (Shapiro and Wilk 1965) indicated that the residuals did not conform to a normal distribution, or when local sphericity assumptions were not met. Arc sine transformations were applied to forb basal cover during both yearly analyses. 
Square root transformations were performed on species richness values during year 2 and horizontal screening cover at $0-0.3 \mathrm{~m}$ during year 1 and at $0-0.3$ and $0.6-0.9 \mathrm{~m}$ during year 2 . Fisher's protected LSD test was used to separate area means within season when there was interaction between main effects.

Table 1. Percent woody canopy cover and percent basal cover of forbs and grasses in most-heavlly used and unused areas of mature, male whitetailed deer home ranges in southern Texas, during 1 Dec. 1986-30 Nov. 1987 (year 1) and 1 Dec. 1987-30 Nov. 1988 (year 2).

\begin{tabular}{|c|c|c|c|c|c|c|}
\hline \multirow[b]{2}{*}{ Variable } & \multirow[b]{2}{*}{ Year } & \multirow[b]{2}{*}{$n^{*}$} & \multicolumn{2}{|c|}{ Used } & \multicolumn{2}{|c|}{ Unused } \\
\hline & & & $\bar{x}$ & SE & $\bar{x}$ & SE \\
\hline \multirow{3}{*}{ Woody } & & & $(\%)$ & & $(\%)$ & \\
\hline & $1^{b}$ & 24 & 89.3 & 7.5 & 58.3 & 6.1 \\
\hline & $2^{b}$ & 32 & 92.4 & 6.7 & 74.2 & 12.1 \\
\hline \multirow[t]{2}{*}{ Forb } & 1 & 24 & 16.4 & 4.3 & 15.9 & 4.2 \\
\hline & 2 & 32 & 1.8 & 0.6 & 2.2 & 0.6 \\
\hline \multirow[t]{2}{*}{ Grass } & 1 & 24 & 13.0 & 1.2 & 16.5 & 1.9 \\
\hline & 2 & 32 & 1.7 & 0.2 & 2.3 & 0.4 \\
\hline
\end{tabular}

"Seasons were pooled.

Area effect $(P \leq 0.05)$ with no season $\times$ area interaction $(P>0.10)$.

\section{Results}

Used areas possessed greater $(P \leq 0.05)$ total woody canopy cover during both years, ranging from 89.3 to $92.4 \%$, compared to unused areas, ranging from 58.3 to $74.2 \%$ (Table 1). Seasonal data were pooled because area $\times$ season interaction was absent $(P>0.10)$.

Table 2. Number of species and height $(m)$ of woody vegetation in mostheavily used and unused areas of mature, male white-tailed deer home ranges in southern Texas, during 1 Dec. 1986-30 Nov. 1987 (year 1 ) and 1 Dec. 1987-30 Nov. 1988 (year 2).

\begin{tabular}{|c|c|c|c|c|c|c|c|}
\hline \multirow[b]{2}{*}{ Variable } & \multirow[b]{2}{*}{ Year } & \multirow[b]{2}{*}{$\mathrm{n}$} & \multirow[b]{2}{*}{ Season $^{\mathrm{a}}$} & \multicolumn{2}{|c|}{ Used } & \multicolumn{2}{|c|}{ Unused } \\
\hline & & & & $\bar{x}$ & $\overline{S E}$ & $\overline{\bar{x}}$ & $\overline{\mathrm{SE}}$ \\
\hline & & & & (m) & & (m) & \\
\hline \multirow[t]{8}{*}{ Species } & 1 & 6 & Winter & 12.7 & 1.4 & 15.5 & 1.8 \\
\hline & & & Spring & 15.0 & 1.8 & 16.0 & 2.2 \\
\hline & & & Summer & 21.2 & 1.2 & 14.3 & 2.9 \\
\hline & & & Fall & 21.3 & 1.8 & 15.8 & 1.7 \\
\hline & 2 & 8 & Winter $^{b}$ & 18.9 & 0.2 & 17.0 & 0.2 \\
\hline & & & Spring ${ }^{b}$ & 21.8 & 0.2 & 18.1 & 0.3 \\
\hline & & & Summer ${ }^{b}$ & 20.4 & 0.1 & 16.0 & 0.4 \\
\hline & & & Fall $^{\mathrm{b}}$ & 20.0 & 0.1 & 16.5 & 0.4 \\
\hline \multirow[t]{8}{*}{ Height } & 1 & 6 & Winter $^{c}$ & 6.2 & 0.5 & 4.5 & 0.4 \\
\hline & & & Spring & 5.4 & 0.3 & 5.0 & 0.3 \\
\hline & & & Summer & 5.4 & 0.2 & 4.9 & 0.3 \\
\hline & & & Fall & 5.0 & 0.2 & 4.9 & 0.3 \\
\hline & 2 & 8 & Winter & 5.5 & 0.2 & 5.0 & 0.2 \\
\hline & & & Spring & 4.8 & 0.2 & 5.1 & 0.2 \\
\hline & & & Summer & 5.4 & 0.2 & 4.9 & 0.6 \\
\hline & & & Fall & 5.2 & 0.2 & 5.4 & 0.5 \\
\hline
\end{tabular}

Area means within season are presented due to season $\times$ area interaction $(P \leq 0.05)$ during 1986-1987 on numbers of species and height.

${ }^{b}$ Area effect $(P \leq 0.05)$ with no season $X$ area interaction $(P>0.10)$.

Area effect within season $(P \leq 0.05)$.

The number of woody species during year 1 did not differ between areas $(P>0.05)$ due to area $\times$ season interaction $(P<0.01)$. Comparisons within seasons indicated that areas used during summer and fall possessed a greater number of woody species
$(P \leq 0.05)$ than unused areas (Table 2). The number of woody species was greater $(P \leq 0.05)$ in used areas compared to unused areas during all seasons in year 2 .

Woody vegetation height differences during year $1(P \leq 0.05)$ were affected by area $X$ season interaction $(P \leq 0.05)$. Used areas

Table 3. Horizontal screening cover (\%) in most-heavily used and unused areas of mature, male white-tailed deer home ranges in southern Texas, during 1 Dec. 1986-30 Nov. 1987 (year 1) and 1 Dec. 1987-30 Nov. 1988 (year 2).

\begin{tabular}{|c|c|c|c|c|c|c|c|}
\hline \multirow[b]{2}{*}{ Year } & \multirow[b]{2}{*}{$n^{n}$} & \multirow[b]{2}{*}{ Height } & \multicolumn{2}{|c|}{ Used } & \multicolumn{2}{|c|}{ Unused } & \multirow[b]{2}{*}{$P$-level ${ }^{\mathrm{b}}$} \\
\hline & & & $\bar{x}$ & $\overline{\mathrm{SE}}$ & $\bar{x}$ & $\overline{\mathrm{SE}}$ & \\
\hline & & (m) & (\%) & & $(\%)$ & & \\
\hline \multirow[t]{6}{*}{1} & 24 & $0.0-0.3$ & 94.1 & 2.0 & 87.6 & 2.4 & 0.0695 \\
\hline & & $0.3-0.6$ & 88.6 & 2.7 & 74.8 & 3.6 & 0.0592 \\
\hline & & $0.6-0.9$ & 83.8 & 3.2 & 66.2 & 4.2 & 0.0564 \\
\hline & & $0.9-1.2$ & 77.1 & 3.7 & 60.0 & 4.2 & 0.0579 \\
\hline & & $1.2-1.5$ & 74.3 & 3.3 & 54.3 & 4.0 & 0.0163 \\
\hline & & $1.5-1.8$ & 71.6 & 3.5 & 51.9 & 3.9 & 0.0218 \\
\hline \multirow[t]{6}{*}{2} & 32 & $0.0-0.3$ & 93.0 & 1.4 & 85.0 & 3.2 & 0.0865 \\
\hline & & $0.3-0.6$ & 89.6 & 1.7 & 80.0 & 3.5 & 0.0729 \\
\hline & & $0.6-0.9$ & 83.8 & 2.0 & 74.0 & 3.6 & 0.0162 \\
\hline & & $0.9-1.2$ & 79.0 & 2.1 & 70.0 & 3.5 & 0.0234 \\
\hline & & $1.2-1.5$ & 72.3 & 2.5 & 65.0 & 3.6 & NS \\
\hline & & $1.5-1.8$ & 70.8 & 2.4 & 63.4 & 3.5 & 0.0543 \\
\hline
\end{tabular}

Seasons were pooled.

bignificance level for area effect comparisons. There were no season $X$ area interactions $(P>0.10)$. Seasons were pooled.

had taller vegetation than unused areas $(P \leq 0.05)$ only during winter (Table 2). No differences in height were present between areas during year 2 .

Horizontal screening cover was greater $(P \leq 0.05)$ in used areas than in unused areas at $0-1.2 \mathrm{~m}(P \leq 0.10)$ and $1.2-1.8 \mathrm{~m}(P \leq 0.05)$ during year 1 (Table 3). Area comparisons during year 2 substantiated data from year 1 as more screening cover was noted at $0-0.6$ $\mathrm{m}(P \leq 0.10), 0.6-1.2 \mathrm{~m}(P \leq 0.05)$, and $1.5-1.8 \mathrm{~m}(P \leq 0.10)$ in used areas compared to unused areas.

Basal area cover of forbs and grasses was similar $(P>0.10)$ between used and unused areas during both years (Table 1). There were no area $X$ season interactions $(P \geq 0.10)$.

\section{Discussion}

Mature, male white-tailed deer appeared to select for certain physical characteristics of their habitat in southern Texas. Presence of greater total canopy cover, more woody species, and more dense screening cover in the most-heavily used areas compared to unused areas support this conclusion. The similarity of herbaceous attributes between areas, coupled with observed differences for woody characteristics, may suggest that deer in this study focused more on brush than herbaceous vegetation when frequenting the most heavily-used areas.

Other researchers have documented the importance of woody canopy cover to deer in Texas. During summer, white-tailed deer densities in southern Texas were reportedly highest when total woody canopy cover exceeded 60\% (Steuter and Wright 1980). In western Texas, total woody canopy cover averaged $63 \%$ in areas with high deer densities, compared to $43 \%$ for areas with low deer density (Wiggers and Beasom 1986).

Canopy cover percentages for used areas in the present study are somewhat higher than previously reported (Steuter and Wright 
1980, Wiggers and Beasom 1986). However, inferences drawn from previous investigations pertain to areas of general deer-use based on visual observations whereas our study used telemetry locations of only mature males at heavily-used areas of their home ranges. Differences in methods used to collect data and the composition of the samples could account for the different canopy cover values. Visual observations most likely would be made when deer were active and thus identify areas used for feeding and travel. It is possible that the most-heavily used areas sampled in our study were bedding sites. Also, sex-related differences have been reported in habitat selection by deer (Verme 1988, Beier and McCullough 1990).

The presence of more screening cover in the most-heavily used areas, compared to unused, indicated that site selection was influenced by horizontal distributional patterns of vegetation. This behavior may have been related to maintenance of a favorable energy balance, as behavioral adaptations to thermal stress are energetically less expensive compared to physiological adaptations (Vaughan 1986). The security cover that these areas also provided likely contributed to eliciting the observed response.

The occurrence of more woody species in the most-heavily used areas was not surprising, because deer habitat is considered to be of high quality when a wide range of vegetation exists (Varner et al. 1977). These heavily used areas may have been utilized for foraging since sites possessing a wider range of browse species are generally thought to provide a more nutritious food supply (Steuter and Wright 1980, Davis 1984). Nutrient composition and digestibility levels of vegetation are so dynamic (Varner et al. 1977, Short 1986) that a diversity of vegetation may allow a selective forager like white-tailed deer (Hofmann 1985) to stabilize nutrient intake throughout the year. An alternative benefit of greater woody species richness could be improved structural diversity. Areas that possess a greater variety of brush species also have a higher complement of varying growth forms, which could have contributed to better screening cover at all height intervals.

Height of woody vegetation did not appear to be important to deer in our study, similar to a report for all ages and sexes of deer from southern Texas (McMahan and Inglis 1974). The lowest average for any seasonal canopy height was 4.8 and $4.5 \mathrm{~m}$ for the most-heavily used and unused areas, respectively. These values are higher than the $1.5 \mathrm{~m}$ recommended by Short (1986).

Forb and grass basal cover did not appear to influence selection of the most-heavily used area within the deer's home ranges. In contrast, McMahan and Inglis (1974) and Steuter and Wright (1980) provided evidence that both sexes, collectively were attracted to sandy loam range sites in southern Texas because of their potential to produce herbaceous vegetation, especially forbs. Other researchers have found woody vegetation to be the major forage component of deer in summer and fall (Arnold and Drawe, 1979, Meyer et al. 1984) and during times of drought (Davis and Winkler 1968).

Our results do not indicate that herbaceous vegetation was unimportant, merely that it appeared to be less important than brush characteristics during the selection of the most-heavily used areas of a mature male's home range. Without knowing with certainty why radio-collared deer frequented some areas while avoiding others, we can make no definitive claims as to what biological function the most-heavily used areas fulfilled. However, we suggest that high levels of woody canopy cover and species richness, and dense horizontal screening cover influenced habitat selection for mature, male deer on the study area.
The habitat characteristics identified as being important to mature, male deer may not be of equal importance to adult female deer. The sexes differ in their habitat use, with males using what appears to be lower quality habitat (Beier and McCullough 1990).

\section{Management Implications}

Our results indicate that habitat management plans for mature, male white-tailed deer in southern Texas should include provisions for creation and/or maintenance of areas possessing 18-20 woody species with a total woody canopy cover $>85 \%$. A diverse mix of woody species with varied growth forms will increase structural and nutritional diversity. Further research is needed to quantify the necessary distributional extent of these habitat attributes. Specific questions include minimum size of areas, juxtaposition with other habitat types, and the percentage of the home range area requiring these characteristics.

Extensive brush removal could reduce habitat quality for mature, male white-tailed deer. Removal of large areas of brush should be considered the worst alternative for managing southern Texas rangelands when production of mature, male deer is the primary management focus. In cases where brush removal may be necessary to facilitate livestock grazing and handling, sites containing important habitat characteristics should be identified and preserved.

\section{Literature Cited}

Arnold, L.A., Jr. and D.L. Drawe. 1979. Seasonal food habits of whitetailed deer in the South Texas Plains. J. Range Manage. 32:175-178.

Barrett, M.W., J.W. Nolan, and L.D. Roy. 1982. Evaluation of a hand-held netgun to capture large mammals. Wildl. Soc. Bull. 10:108-114.

Beasom, S.L., W. Evans, and L. Temple. 1980. The drive net for capturing western big game. J. Wildl. Manage. 44:478-480.

Beier, P. and D.R. McCullough. 1990. Factors influencing white-tailed deer activity patterns and habitat use. Wildl. Monogr. 109.

Box, T.W. and J. Powell. 1965. Brush management techniques for improved forage values in South Texas. Trans N. Amer. Wildl. Conf. 30:285-296.

Cain, S.A. and G.M. de Oliveira Castro. 1959. Manual of vegetation analysis. Harper and Brothers. New York, N.Y.

Canfield, R.H. 1941. Application of the line interception method in sampling range vegetation. J. Forest. 39:388-394.

Correll, D.S. and M.C. Johnston. 1970. Manual of the vascular plants of Texas. Texas Res. Found., Renner.

Davis, E. 1984. Basic white-tailed deer biology and habitat requirements, p. 52-55. In: C. W. Hanselka (ed.), Proc. brush country wildlife symposium, Tex. Agr. Ext. Serv., Texas A\&M Univ., College Station, Tex.

Davis, R.B. and C.K. Winkler. 1968. Brush vs. cleared range as deer habitat in South Texas. J. Wildl. Manage. 32:321-329.

Fulbright, T.E. and S.L. Beasom. 1987. Long-term effects of mechanical treatments on white-tailed deer browse. Wildl. Soc. Bull. 15:560-564.

Heady, H.F., R.P. Gibbens, and R.W. Powell. 1959. A comparison of the charting, line intercept, and line point methods of sampling shrub types of vegetation. J. Range Manage. 12:180-188.

Hofmann, R.R. 1985. Digestive physiology of the deer-their morphophysiological specialization and adaptation. p. 393-407. In: P.F. Fennessy and K.R. Drew, eds. Biology of deer production. R. Soc. N.Z. Bull. 22.

Kie, J.G., M. White, and F.F. Knowlton. 1979. Effects of coyote predation on population dynamics of white-tailed deer. Proc. First Welder Wildl. Found. Symp. 1:65-82.

McMahan, C.A. and J.M. Inglis. 1974. Use of Rio Grande Plain brush types by white-tailed deer. J. Range Manage. 27:369-374.

Meyer, M.W., R.D. Brown, and M.W. Graham. 1984. Protein and energy content of white-tailed deer diets in the Texas Coastal Bend. J. Wildl. Manage. 48:527-534

Nudds, T.D. 1977. Quantifying the vegetative structure of wildlife cover. Wildl. Soc. Bull. 5:113-117. 
Pollock, M.T., S. Demarais, and R.E. Zaiglin. 1990. An efficient retractable mobile antenna tower for radio-telemetry studies. Texas J. Sci. 42:49-53.

Pope, C.A. III, C.E. Adams, and J.K. Thomas. 1984. The recreational and aesthetic value of wildlife in Texas. J. Leisure Res. 16:51-60.

Ramsey, C.W. 1965. Potential economic returns from deer as compared to livestock in the Edwards Plateau region of Texas. J. Range Manage. 18:247-250.

Rollins, D., F.C. Bryant, D.D. Waid, and L.C. Bradley. 1988. Deer response to brush management in central Texas. Wildl. Soc. Bull. 16:277-284.

Severinghaus, C.W. 1949. Tooth development and wear as criteria of age in white-tailed deer. J. Wildl. Manage. 13:195-216.

Shapiro, S.S. and M.B. Wilk. 1965. An analysis of variance test for normality (complete samples). Biometrika. 52:591-611.

Short, H.L. 1986. Habitat suitability index models: White-tailed deer in the Gulf of Mexico and South Atlantic coastal plains. U.S. Fish Wildl. Serv. Biol. Rep. 82(10.123).

Springer, J.T. 1979. Some sources of bias and sampling error in radiotriangulation. J. Wildl. Manage. 43:926-935.

Steel, R.G.D. and J.H. Torrie. 1980. Principles and procedures of statistics: a biometrical approach. McGraw-Hill Book Co. New York, N.Y.

Steuter, A.A., and H.A. Wright. 1980. White-tailed deer densities and brush cover on the Rio Grande Plain. J. Range Manage. 33:328-331.
Stevens, J.W. and D. Arriaga. 1985. Soil survey of Dimmit and Zavala counties, Texas. USDA, Soil Conserv. Serv.

Teer, J.G. and N.K. Forrest. 1968. Bionomic and ethical implication of commercial game harvest programs. Trans. North Amer. Wildl. Conf. 33:192-204.

Varner, L.W., L.H. Blankenship, and G.W. Lynch. 1977. Seasonal changes in nutritive value of deer food plants in south Texas. Proc. Annu. Conf. Southeast. Assoc. Fish and Wildl. Agencies. 31:99-106.

Vaughan, T.A. 1986. Mammalogy, 3rd ed. Saunders College Publishing, N.Y.

Verme, L.J. 1988. Niche selection by male white-tailed deer: an alternative hypothesis. Wildl. Soc. Bull. 16:448-451.

Welch, T.G. 1986. Acres of Texas rangeland treated for brush and weed control. Tex. Agr. Ext. Serv. RS 3-1.

White, G.C. and R.A. Garrott. 1984. Portable computer system for fiel processing biotelemetry triangulation data. Outdoor Facts, Game Information leaflet \#110, Colorado Div. Wildl.

White, G.C. and R.A. Garrott. 1990. Analysis of Wildlife Radio-Tracking Data. Academic Press, Inc., N.Y.

Wiggers, E.P. and S.L. Beasom. 1986. Characterization of sympatric or adjacent habitats of 2 deer species in west Texas. J. Wildl. Manage. 50:129-134. 